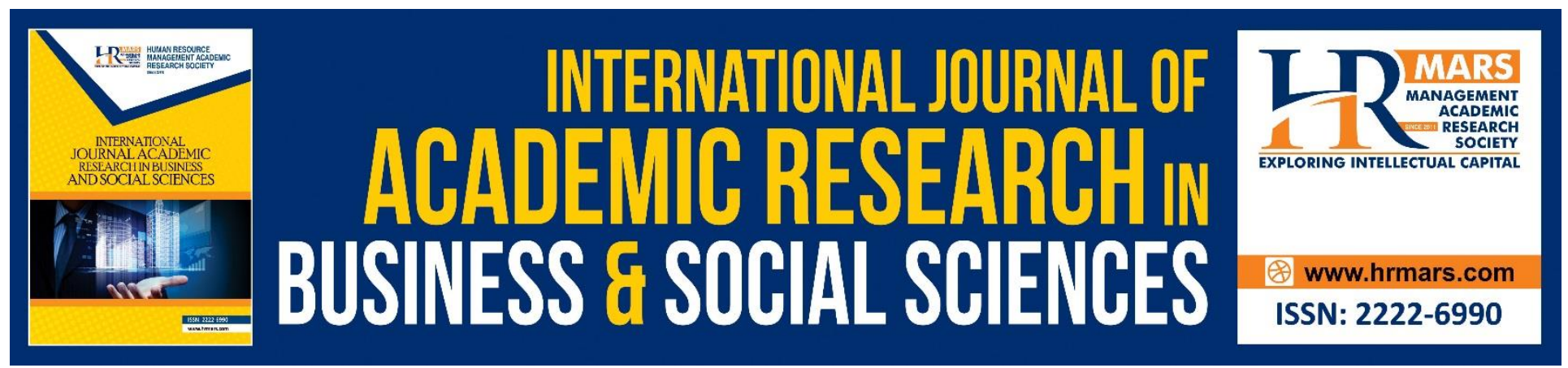

\title{
Examining the Issue of Islam and Muslims in the Media: A Perspective of Malaysian Media Practitioners
}

Fauziah Hassan, Sofia Hayati Yusoff, Osama Kanaker, Muhamad Zaki Mustafa \& Siti Zobidah Omar

To Link this Article: http://dx.doi.org/10.6007/IJARBSS/v10-i16/8300

DOI:10.6007/IJARBSS/v10-i16/8300

Received: 12 October 2020, Revised: 10 November 2020, Accepted: 28 November 2020

Published Online: 16 December 2020

In-Text Citation: (Hassan et al., 2020)

To Cite this Article: Hassan, F., Yusoff, S. H., Kanaker, O., Mustafa, M. Z., \& Omar, S. Z. (2020). Examining the Issue of Islam and Muslims in the Media: A Perspective of Malaysian Media Practitioners. International Journal of Academic Research in Business and Social Sciences, 10(16), 162-174.

Copyright: (c) 2020 The Author(s)

Published by Human Resource Management Academic Research Society (www.hrmars.com)

This article is published under the Creative Commons Attribution (CC BY 4.0) license. Anyone may reproduce, distribute, translate and create derivative works of this article (for both commercial and non-commercial purposes), subject to full attribution to the original publication and authors. The full terms of this license may be seen at: http://creativecommons.org/licences/by/4.0/legalcode

Special Issue: Youth and Community Wellbeing: Issues, Challenges and Opportunities for Empowerment V2, 2020, Pg. 162 - 174

Full Terms \& Conditions of access and use can be found at http://hrmars.com/index.php/pages/detail/publication-ethics 


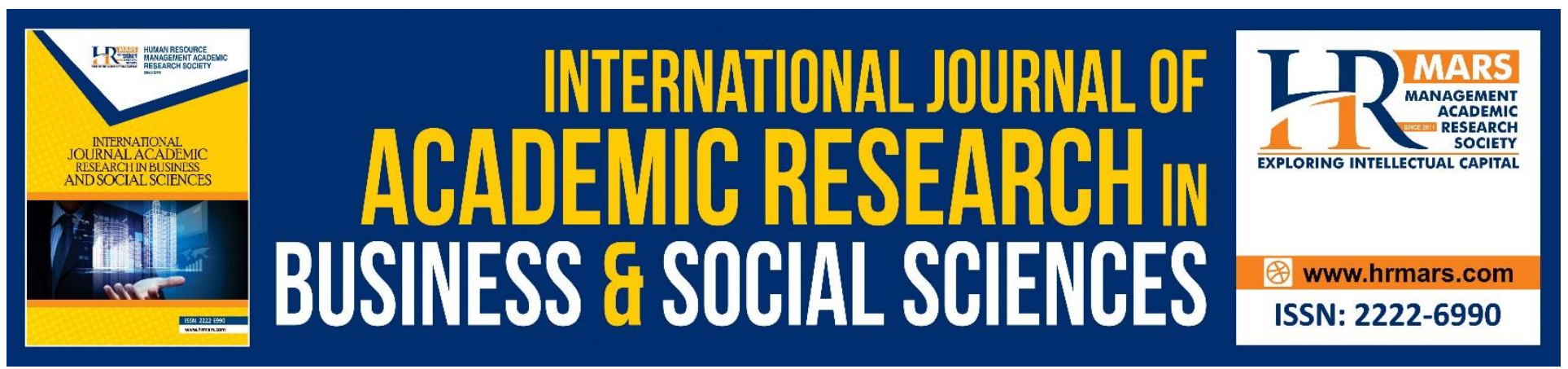

\title{
Examining the Issue of Islam and Muslims in the Media: A Perspective of Malaysian Media Practitioners
}

\author{
${ }^{2}$ Fauziah Hassan, ${ }^{2}$ Sofia Hayati Yusoff, ${ }^{2}$ Osama Kanaker, ${ }^{2}$ Muhamad \\ Zaki Mustafa \& ${ }^{1,3}$ Siti Zobidah Omar \\ ${ }^{1}$ Institute for Social Science Studies, Putra Infoport, Universiti Putra Malaysia, 43400, UPM Serdang, \\ Selangor, Malaysia, ${ }^{2}$ Communication Program, Faculty of Leadership and Management, Universiti \\ Sains Islam Malaysia, Nilai, Negeri Sembilan, Malaysia, ${ }^{3}$ Faculty of Modern Languages and \\ Communication, Universiti Putra Malaysia, 43400, UPM Serdang, Selangor, Malaysia \\ Email: fauziah.hassan@usim.edu.my,zobidah@upm.edu.my
}

\begin{abstract}
Researching on Islam and Muslims-related issues in the media have been a never-ending debate and always have been updated time by time. It catches the attention of academics, scholars, preachers, researchers to discuss on the alternative platform in reducing or somewhat controlling what the media should report about particularly on Islam and Muslims issues. The aim of this study is to examine the reportings related to Islam and Muslims issues of the Western newspapers. Interviews were conducted among eight Malaysian media practitioners to identify how they translate the meaning of work as a journalist in Islamic context, and also to find out their best practices in producing a balanced and fair news reporting. The interviews were later transcribed verbatimly, analyzed and deliberated their experiences towards this issue. Results show that they believe as Muslim journalists, they should be true, trusted and not bias in reporting news. Further, they also find out that having good references from experts and doing some research before reporting on any issues are very important especially in reporting news globally. Thus for them, the adaptation of good journalistic practices represent a positive image of Islam and Muslims in order to continue creating a surrounding of Islam and Muslims at present and in the future.
\end{abstract}

Keywords: Islam and Muslims Issues, News Reporting, Malaysian Media Practitioners, Balanced and Fair Reporting.

\section{Introduction}

Researching on issues related to Islam and Muslims in the media is a never ending debate and always updated time by time. It catches attention from academics, scholars, preachers, researchers to 
discuss on the alternative platform in reducing or somewhat controlling what the media should report about particularly on Islam and Muslims issues. From the remarkable incident happened on $11 / 9$, it has moved to other issues such as violence, conflicts, indiscrimination, economic disparity, crisis, poverty etc which involved Islam and Muslim societies.

News coverages that mostly portray Islam and Muslims are negatively framed by the global media. Aljazeera in 2019 has reported that world leaders faced few major issues such as Islamophobia, poverty, the Rohingya refugee crisis, the economic disparity faced by Niger (one of the OIC members country) and the issue of Uighur minority in China. Recently, the Yemen crisis such as unlawful airstrikes, attacks on civil society, discrimination, violence against women, children and armed conflict and many more have been reported widely by the BBC news on 19 June 2020. On top of that, the largest country in South East Asia region, India has become a main target to be blamed for a pandemic of Covid-19 as reported by The Guardian on 13 April 2020. Not only that, India also faced other issues such as Muslims were burned alive in their homes or dragged out into the streets and lynched and Muslim businesses and property were also set alight. The violence raged across the north-east of India's capital for four days as mosques were set alight (The Guardian on 1st March 2020).

This article aims to provide a room for improvement especially on how to write news related to Islam and Muslims issues. Therefore, this study is believed significantly to fill the research gap found in previous research as this research concentrated on how media should report issues surrounds Islam and Muslims in Muslim-majority country such as Malaysia. Furthermore, the most significant and imperative of this research is to discover the best practice to enlighten the new miracle of reporting for Islam and Muslim issues by putting aside the formula from the West.

This research gained the data by interviewing the media practitioners. As we know, each media industry has its own policies and standard of procedures in writing and producing news articles. So, no matter what, the media practitioners such as editors and journalists have to follow all the rules and procedures and ultimately, without changes, thus, there will be no new improvements. It is true that there is a guideline to report all news fairly and justly. But to what extent is this guideline applied, especially to news related to Islam? Perhaps the findings of this research will give some ideas to the Western news media organizations as well on how to set up new practices and procedures especially in reporting on Islam and Muslim stories through the practice, research and journal publications. The other significant point to consider is the "practice" part to help news media organization. The practice of the new approach in news reporting may increase the awareness of the public particularly on this global issue. This article could also substantiate and help to increase consciousness on the importance of how to write about Islam fairly which eventually can help promoting the image of Islam and Muslims with values and respect. At the end of the interview, this research aimed at finding out whether the media practitioners have a knowledge about Islam and Muslims and aware on how to produce a good style of news reporting specifically on the issue of Islam and Muslims around the globe.

In this article, the aim is formulated into two questions: 
1. How Muslim journalists should anchor the meaning of their work in the context of Islam and what that means for the kind of journalism they practice?

2. What is the best practice can be applied by media practitioners, writers, students, researchers and etc. in order to produce and practice a balanced and fair of news reporting?

\section{Portrayal of Islam and Muslims Pre and Post 9/11}

The position of Islam and Muslims in the media and public discourse has shifted since the terrorist attacks of September 11 in 2001. Nacos and Torres-Reyna (2007) indicated that a dramatic increase of Islam mentioned in news appeared immediately after the attack. Poole and Richardson (2006) similarly reported that the September 11 attacks have made Islam and Muslims became newsworthy. However, Said (1997); Shaheen (1997); Nektaria et al (2015) pointed out that Islam was not only being discussed immediately after the attack but even before the attack when the Western media had been strongly critical in their coverage on Islam and Muslims. This is in line with the opinion of Huntington (1996) that Islam has been described as the antagonist or enemy of the West since the fall of the Soviet Union.

A study by Abu Shahid (2015) on the representation of Muslims in the pre of September 11 attacks resulted Muslims as funny, clumsy, religious profiling, discrimination, terrorism and dangerous. This is based on the analysis of two American films named; True Lies (1994) and The Siege (1998). In the film True Lies, Palestinians were portrayed as dirty, clumsy, funny, demonic, despicable people and had exploded a nuclear bomb to the US. Throughout the film, the director James Cameron wrongly represented the Palestinians as a terrorist group called 'Crimson Jihad' and this group was portrayed as violent, irrational and possessed extreme hatred towards Americans. On the other hand, The Siege (1998) portrayed Muslims as terrorists and become the backbone of US secret service as their becoming terrorists. This is because, the film wants to inform the viewers how CIA recruits and trains Muslims to be terrorists by providing trainings and support to the soldiers opposing Saddam Hussein's government and eventually, leaving them when the alliance is complete.

After 9/11 attacks, Ibrahim (2010) analysed the transcripts and videos of news aired by three national networks in the US, namely the American Broadcasting Company ( $A B C)$, Columbia Broadcasting System (CBS) and National Broadcasting Company (NBC) for 14 days after 9/11 - from 11 September to 25 September 2001. She categorized the findings into two sections: internal Islam (referring to the Muslims who lived in the US) and external Islam (referring to the Muslims who lived outside the US). The results showed Islam was represented as the most peaceful religion, with NBC repeatedly showing images of Muslims waving the American flag and this indicated that Muslims who were living in America should not be harmed and must be protected and treated with dignity and humanity, even though hate crimes against Muslims increased in the first two weeks after 11 September 2001. The $A B C$ also broadcast a live press conference with New York Mayor, Rudy Giuliani, emphasizing that the public should not display their anger and hatred towards the Muslims and Arab communities as they are not all responsible for the attacks. In contrast, Muslims who lived outside the US were represented as violent and had no respect for America by burning the American flag. She further 
elaborated that another immense issue that has been lingering about Muslims is on "jihad". The meaning of "jihad" has been misinterpreted by the Western media as a "holy war". For instance, news anchor Bob Woodruff, mentioned that poor students in Pakistan and Afghanistan were given free food, education and clothing while studying the Koran and had learned about the holy war (jihad). These differences in findings showed that Muslims lived in America supported the country but those lived outside America reacted otherwise.

\section{Media Representation of Islam and Muslims}

The representation of Islam and Muslims continued through a study by Morey and Yaqin (2010) claimed that Islam and Muslims appeared as problematic, troubling and affecting Western freedoms, as the media seemed to continue playing with the issues of veiling, cartoons of the Prophet Muhammad, and the Middle East conflicts such as in Afghanistan, Iraq and Palestine. A year later, Morey and Yaqin (2011) discovered that the contemporary media framing on Islam showed Muslims as dangerous, hostile, threatening and untrustworthy and even as terrorists to describe the Muslims' way of life.

Kabir and Bourke (2012) studied how New Zealand newspapers represented Islam and Muslims. They found that most of the news on Islam and Muslims were contributed by overseas news agencies as news sources. This indicates that most of the news reports came from international agencies such as foreign newspapers and Associated Press (AP). Interestingly, the editorials of the newspapers did provide a positive image of Islam and/or Muslims with a few exceptions. In terms of the coverage, the frequency of local news coverage was low, indicating that local events in relation to Islam or Muslims in New Zealand were not really important but the international coverage of Islam or/and Muslims was relatively significant to these newspapers. Other than that, local news events carried insignificant importance to the newspapers in New Zealand and the news correspondents of the newspapers studied made an insignificant contribution as well. However, the consistent coverage of Islam and Muslims is enough to show the importance of Islam as a subject in New Zealand newspapers.

A study by Rahman and Emadi (2018) found that the news stories on Islam and Muslims were found more negative especially in 2014 and 2017. Based on the news stories, Muslims are perceived as homogeneous violent group and ambivalent. Not only that, the media visuals also portrayed falsifications, contradiction and negative representation of Islam and Muslims. Recent study in 2020 by Rahman on the representation of Muslims identity by the media after the Christchurch mosque massacres in social media news feed of Facebook and Twitter surprisingly to be more human angle, depicting peace, love and forgiveness as the New Zealand's newspapers have promised not to provide a space for rhetoric Islam. However, the issue of Charlie Hebdo a satirical France newspaper has created and triggered anger among Muslims. According to the AP news on October 30, 2020, this newspaper always portrays caricatures that offend certain groups or individuals as they claim Islam is the religion which threatens democracy, intolerance and oppression.

Based on the discussion above, this study assumes that the nature of representations of Islam and Muslims in the Western media are still under a cloud with numerous studies proving that Western 
media still represent the religion of Islam and Muslims negatively. Whether in media representation, news reporting or language used in the reporting, all have shown that Islam and Muslims are still viewed unfavourably by Western media. Not only that, the researchers observed that various methodologies used in conducting research also showed that all news, videos, cartoons and other contents about Islam and Muslims were prone to the same negative view. This is in line with Eid (2014) who also discovered that the portrayal of Islam and Muslims in the Western media revealed that the media is lean towards an emphasis on stereotypes and discriminatory rhetoric, casting an unfavourable light on Islam and Muslims. He also highlighted that Islam and Muslims have been framed by the Western media within two framings: in conflict with the West and associated with terrorism/extremism or violence due to the depiction of Islam and Muslims as negative or "Other" for Western societies.

\section{Research Objectives}

1) To understand the meaning of journalists in Islamic context and practice.

2) To identify the best practice in producing a balanced and fair reporting on issues related to Islam and Muslims

\section{Research Design and Methodology}

This article is solely based on in-depth interviews conducted within the project titled "Developing Acrostic Model for Journalism Students in Reporting News Related to Islam/Muslims: A Way to Sustain the Positive Reporting on Islam/Muslims Issues". We have interviewed eight Malaysian media practitioners. All the interviews were semi-structured and concentrated on main questions, were tape-recorded and later transcribed. An important intention with the interviews has been to try to capture the informants' points on the scenario of current image and trend of news reporting related to Islam and Muslims issues. Then, the authors contacted all informants via purposive sampling method. According to Lawrence, et al. (2016) detailed out that the purposive sampling has been used widely in qualitative research which is potentially used to find and identify informants who have much information that relate to the research interest. Thus, the researchers also implemented the same thing and the purposive sampling (non-probability sampling) has been preferred as this study is focusing on how to develop a model of Islamic news writing. In addition, Creswell and Clark (2011) added that the informants or individuals or groups must be selected among those who are knowledgeable and having experienced with the phenomenon or interest. Thus, the informants specifically were selected based on their expertise, educational background and their valuable experiences in newsroom in writing news on Islam and Muslims and general issues. To reach a data saturation is another challenge in purposive sampling, however the data saturation may emerge from the data themselves (Glaser and Strauss, 1967). For this research, numbers of informants have been limited to five informants from different news organisations as all the new data have been emerged and developed. All interviews were conducted in Malay language and later translated to English language. Each interview session lasted within one hour. The informants were told about the purpose of the study and that participation was voluntary and the use of anonymity was also guaranteed. Data were collected, and analyses were conducted throughout the research process. The analysis began by listening to the taped interviews and reading the transcriptions and documentation. The interviews were then coded according to the research questions that had been identified. 


\section{Findings}

Listening to the interviews can be very mind-blowing. Their experiences, ideas and viewpoints have depicted the new picture of how Islam and Muslims issues are being reported. Based on these interviews, we analysed and discussed their experiences thoroughly as the findings are very much important in producing and practicing a balanced and fair of news reporting. The researchers focused on two main themes found in this article which match to the major concern of the researchers.

\section{Practicing as Journalists in Islamic Context}

As professional media practitioners, work ethics is inevitable. Furthermore, as journalists they have to ensure that all the information, news, videos and etc. must be disseminated following to the Islamic teaching and principles as the society is overdependent on media. With regards to identifying how journalists practice the concept of Islam in their work life, Informant 1 addressed that;

Based on the interview with informant 1, individual assessment is important in determining the news' authenticity based on Islamic ethics. He/she also stated it is crucial for a muslim journalist to obtain good islamic foundation, practices moderation and always refers to the experts should he/she has questions pertaining to Islam before he/she presents the story to readers. Besides, he claimed that media practioners should be able to relate the writing to Islamic teachings. For instance issues on the almsgiving (zakat), pilgrimage (performing hajj), and pilgrimage management organisation or popularly known as Tabung Haji. (Informant 1).

The above statement also has been supported by Informant 7 who said that;

A journalist must possess Islamic knowledge if he wants to report news about Islam (Informant 7)

Another issue highlighted is a media practitioner must refer to any field experts to avoid any misperception. This is because, in order to practice Islamic work ethics at workplace, the information must be disseminated with proper checking. The Informant 1 continued saying;

Do not be lazy to find out the credible sources for your writing. As an Islamic journalist, who always write about Islamic issues you need to know whom you can refer to, make sure the writing is not wrong, not misunderstood by the readers to avoid conflict. Especially this is the era of social media where any misunderstanding on certain issues can go viral. (Informant 1).

Based on this, there is a need for journalists or media practitioners to have extensive or extra knowledge and a good understanding of an issue that need to be reported. In addition, the editor should also have a good understanding of the issue as well. This is to avoid misinformation in conveying information and since the priority of having relevant knowledge among journalists is important.

This statement is supported by Informants 2 and 8 who stated that; 
It is important for Muslim journalists to have a good, moderate and knowledgeable religious background especially when they are required to write on Islamic issues. Apart from that, they also must hold two main principles which are being truth and honest. They are the characteristics of an Islamic journalist. It is called the Ethics of Journalists. The important thing is to follow Islam, being honest and trustworthy (Informant 2).

Journalists carry very huge responsibility. We have to ensure that the community will understand after reading news or watching news on TV and etc. in my opinion, regardless you are Muslim or non-Muslim, you should be responsible and ethical (Informant 8).

However, with the advances and developments in media and technology, the role of journalists becomes very challenging. This is because apart from writing and gathering news, they also must support to the da'wah activities via media. They also have to ensure that all contents in social media are following the ethics.

As journalists, they should have good intentions when producing or reporting news. Let say you carry the image of Islam, you need to have the characteristics as a Muslim. Therefore, our report/news must be true, impartial and not to take advantage of others, be balanced, and ensure that all news must be comprehensive. I agree that Muslim journalists should have good intentions when reporting something (Informants 5 and 6).

Therefore, it can be concluded that, with regards to strengthening the Islamic work ethics as a media practitioner we must apply few criteria such as being honest and trustworthy. Media practitioners must not be biased and possess good knowledge about Islam. If they do not have knowledge related to Islam or any issues related to Islam, they should refer to those who have the expertise and knowledge on the matter. All of the above are highly depending on the trust and self-responsibility of the media practitioner himself in practicing Islamic work ethic.

\section{The Practice of Balanced and Fair News Reporting}

The space for writing and disseminating information is now becoming faster with the presence of social media which is presently the main platform to communicate. However, what needs to be realized is how to ensure that the media content is having a balanced and fair reporting or writing. According to Informant 5, the main challenge is to ensure the process of fact checking. This is because anything that is disseminated or conveyed through social media is not through a review process as it can be disseminated by anyone.

Any news or report published from official websites or news portal must go through the process of fact checking. This is what we called as an editorial process. In social media there is none. (Informant 5)

Along with this, informant 1 added in order to produce a good and balance writing, application on principles of journalism that stress on the usage of $5 \mathrm{~W} 1 \mathrm{H}$ is required. This is to ensure the non-bias and objective writing be it issue on religion, economy, crime, social or others. 
Apart from the $5 \mathrm{~W} 1 \mathrm{H}$ concept, adherence to the ethics or house-style of each organization also plays a role. This is because every media organization has its own way and method as well. It stated by Informant 8:

So this is what we need to understand especially from the media government such as RTM, Bernama, Information Department. We do not only need to report responsibly but we need to adhere the government media ethics before we release the news (Informant 8).

This is in line with Informant 4;

The way of writing depends on which news organization you work with. In RTM, the most important thing is news must be factual and accurate because RTM is the official media for government (Informant 4).

On the other note, to produce good and balanced writing is by referring to credible sources such as the field experts and legitimate previous reports. This is stated by Informant 3 who suggested that before completing the writing, it would be better if each media practitioner refers to authentic and credible sources from related scientific studies.

So, my experience before making a reporting for global issues, I will do a research first. For example, I would refer to previous reports which is relevant or scholarly reports that have been published. Or we referred to any field experts on particular issues discussed such as issue on global warming, islamophobia. Then our report would be very original and grounded (Informant 3).

Another method to produce a balanced and fair writing is by doing a research and understanding the issues comprehensively. Therefore, it is important for a media practitioner to understand the news or issues being discussed in various contexts.

So before we do our reporting, we will do a research, we will identify the sources, so that the news we will publish is having a credibility- news that has authenticity and in accordance with RTM's own authentic motto. (Informant 8).

This is in line with Informant 6 who stated that if it is necessary to write news or articles related to international news such as issues related to Syria, he will see and find official news sources either through the official news portal or contacting the sources. In addition, he also referred to experts to get factual input.

Regarding reporting International issues such as Syria, we need to have someone who is very expert and knowledgeable. This is the challenge. We need someone who is very 
conversant and familiar in what is happening in Syria, so they can explain to the society as they understand the issue. (Informant 6).

Informant 7, on the other hand, stated that the method to produce a balance and fair news writing, especially on global issues, is conducted without taking any publication from international media portals. Therefore, he would inform his staff to ensure that every writing or reporting related to international issues should be processed according to the house-style of TV Alhijrah because Muslim journalists should avoid from copying the writing style of Western media reporting on issues related to Islam and Muslims. Apart from that, he also made a reference to Channel News Asia and Arab News portals which are more detailed in commenting on global issues.

At the same time, journalists and editors need to be careful and cautious in the selection of news angle because TV AlHijrah is a news organization which defend the rights of Islam and Muslims. This is because foreign media agencies and international news portals are too stereotypical about Islam and Muslims such as Reuters, they are on the side of Israel which is very cruel to Muslims (Informant 7).

Among the other challenges mentioned in producing a balanced writing are also stated by Informant 7 as below:

In commenting on global issues, journalists do have the right to practice freedom of expression but it does not mean they are allowed to speak out on any issues. This is the main challenge for journalists. This is because in expressing their opinions, they need to take care of the racial sensitivities of other countries to preserve the diplomatic relations that have been established between Malaysia and other countries. For example, our country needs to maintain diplomatic relations with China so we cannot aggravate the situation by raising the issue of Uyghur ethnicity in China. Criticism through writing is okay but we need to limit the content in order to avoid the diplomatic relations of the country being affected (Informant 7).

The same thing was also raised by Informant 8 who stated that the sensitivity regarding reporting to global issues needs to be refined properly. This is because fair and balanced media content can create a harmonious atmosphere.

In local media we have various ethics that we need to follow before we release the news. This is even more crucial when it comes to sensitive issues. We understand that our society has various languages, ethnicities and even religions. So, the news/reports/articles that we disseminate are not only honest, but we have to make sure that it will not offend the sensitivity of the community. Unlike the local media, western media reportings never abide by the ethics (Informant 8).

Based on interviews with media practitioners, there are several things that need to be taken into account to produce fair and balanced reporting. For an example, the need to do a review for each 
report before disseminated. In fact, the writing needs to follow the principles of journalism such as being impartial and objective. To avoid bias in news writing, the media practitioners should refer to an expert on an issue and not simply take what is reported by international media portals especially news related to Islam and Muslims to protect harmony and sensitivity.

\section{Conclusion}

The nature of reporting on Islam and Muslims has become very problematic in nature and has been the utmost focus of research (Ewart, Pearson, \& Healy, 2016). The findings discussed above are focusing on the nature of being Muslim journalists and how they anchor their responsibility in Islamic context. In addition to this, this article also aims at finding out the techniques in producing balance and fair news. Thus, the researchers have simplified the findings on techniques in producing balance and fair news into the following formula:
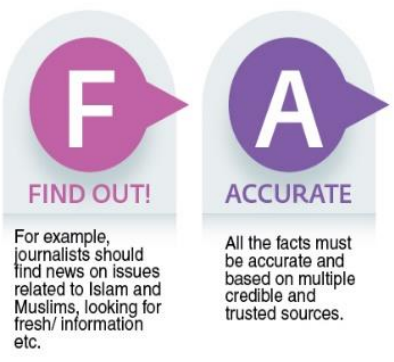
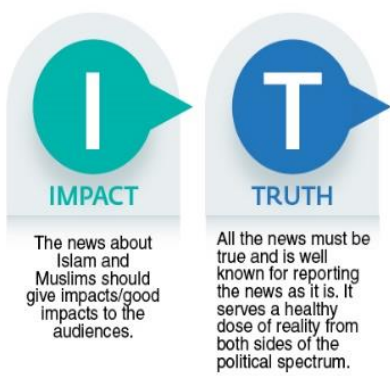
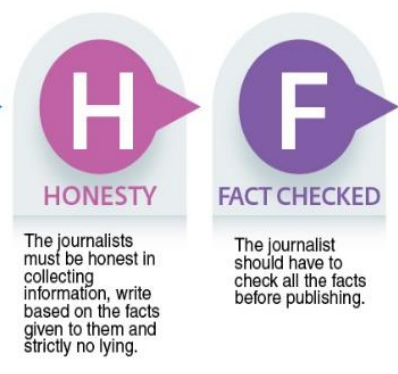
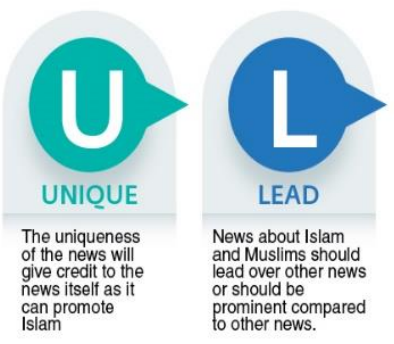

Figure 1: Islamic Journalistic Model of News Writing (Copyright: LY2019007145)

The above model shows the acrostic guide in news writing. This model is designed to guide and help the media practitioners or students or any individuals who want to create content is either in form of writing or video or photos and etc. For example, a journalist can check whether news they write has all eight criteria as mentioned above. For instance, the above model encourages journalists to be "Truth" and "Honest". This is in line with Islam mandates the ethical grounds of mutual respect, amanah (trust) and amr bilma'ruf wanahi almunkar (enjoining good and forbidding evil). This concept, if implemented in human communication, guarantee stability, peace and mutual love among mankind. Therefore, journalist or individual should do a cross check before producing any media content. Other than that, the characteristic of "Impact" also very much related with Ewart et al. (2016) who suggested in their study that the journalists not only refer to the expert, but also contact those who are affected with regards to develop more understandings and increase impacts to their reportage.

On the other hand, the coverage of Islam in the media is not always negative. Muslims could convey their religion to the worlds. However, in most cases Islam is presented superficially. The magnanimity, beauty and tolerance of Islam are insufficiently covered. This scenario of the media requires Muslims to cover Islam in its reality, not through the actions of Muslims. Therefore, there has long been a real need to study on how Islam has been pictured by its own Muslim country such as Malaysia. The 
importance to highlight our own newspapers in covering issues related to Islam and Muslims as an alternative way to show the positive side of Islam is hopefully meaningful. Yet, at present, there is no way to prove until the academic research has been done. Furthermore, the little work on this topic is very limited and yet narrowly disseminated.

Based on this interview which focused on media practitioners' perspective and perceptions on what is the best practice in producing a balanced and fair writing, the researchers believe that this is the first step to have a perspective from media practitioners in addressing some of the practices in how reporting news on Islam and Muslims should be implemented. According to Ewart et al. (2016) apart from media practitioners, understanding the process of news writing by following the proper guideline could help individual, students or citizens to produce a balanced and fair media content. For students, this can help them to familiarize themselves with the process of gathering, writing and train them to improve their skills in reporting. Indeed, the researchers believe that the adaptation of journalistic practices in relation to represent positive image of Islam and Muslims is needed in order to have good surrounding of Islam and Muslims present and in the future.

\section{Funding Acknowledgement}

This research project has been funded by Research Management and Innovation Centre of Universiti Sains Islam Malaysia under a Short Grant Project (PPPI/FKP/0217/05100/10918).

\section{References}

Abu Shahid, A. (2015). Muslims in pre-and post-9/11 contexts. International Journal of Comparative Literature \& Translation Studies, 3 (3), 51-59. doi: 10.7575/aiac.ijclts.v.3n.3p.52.

BBC. (2020). Yemen crisis: Why is there a war? https://www.bbc.com/news/worldmiddle-east-29319423

Charlton, A., \& Hinnant, L. (2020). Charlie Hebdo: Proud to provoke Islamists, despite violence. Retrieved at https://apnews.com/article/charlie-hebdo-france-provoke-islamists39c19096470e74cf5ed1ff8e5c4ac0db.

Eid, M. (2014). The new era of media and terrorism. Studies in Conflict \& Terrorism, 36(7), 609615, doi: 10.1080/1057610X.2013.793638.

Ewart, J., Pearson, M., \& Healy, G. (2016) Journalists' and Educators' Perspectives on News Media Reporting of Islam and Muslim Communities in Australia and New Zealand, Journal of Media and Religion, 15:3, 136-145, DOI: 10.1080/15348423.2016.1209391

Glaser, B. G., \& Strauss, A. L. (1967). The discovery of grounded theory: Strategies for qualitative research. Aldine de Gruyter, Hawthorne, New York, USA.

Huntington, S. (1996). The clash of civilisations and the remaking of world order. New York: Simon \& Schuster.

Ibrahim, D. (2011). The framing of Islam on network news following the September $11^{\mathrm{TH}}$ attacks. The International Communication Gazette, 72(1), 111-125. doi: 10.1177/174804850935034

Kabir, N. S., \& Bourk, M. (2012). Representing Islam and Muslims in New Zealand newspapers. Journal of Muslim Minority Affairs, 32(3), 324-338. doi:10.1080/13602004.2012.727293.

Lawrence, A. P., Horwitz, S. M., Green, C. A., Wisdom, J. P., Duan, N., \& Hoagwood, K. (2015). Adm Policy Ment Health. 2015 Sep; 42(5): 533-544. doi: 10.1007/s10488-013-0528-y. 
Morey, P., \& Yaqin, A. (2011). Framing Muslims: Stereotyping and representations after 9/11. Cambridge, MA: Harvard University Press.

Morey, P., \& Yaqin, A. (2010). Muslims in the frame. International Journal of Postcolonial Studies, 12 (2), 145-156. doi: 10.1080/1369801X2010.489687.

Nektaria, A., Pelagia-Maria, V., Theodora, N., \& A., P. E. (2015). Innovative Pedagogical Approaches in the Greek Context: The case of Fourfouras primary school. Multilingual Academic Journal of Education and Social Sciences, 3(1), 74-90.

Nacos, B. L., \& Torres-Reyna, O. (2007). Fueling our fears: Stereotyping, media coverage and public opinion of Muslim Americans. (Review of the Book by Mahmoud Eid) Lanham, MD: Rowman \& Littelfield Publishers.

Rahman, K. A. (2020). News media and the Muslim identity after the Christchurch mosque massacres, Kōtuitui: New Zealand Journal of Social Sciences Online, 15:2, 360-384, DOI: 10.1080/1177083X.2020.174750.

Rahman, K. A., \& Emadi, A. (2018). Representations of Islam and Muslims in New Zealand media. Pacific Journalism Review. 24(2):166-188.

Said, E. W. (1997). Covering Islam: How the media and the experts determine how we see the rest of the world. New York: Pantheon

Shaheen, J. G. (1997) Arab and Muslim stereotyping in American culture. Washington, DC: Center for Muslim-Christian Understanding: History and International Affairs, Georgetown University.

The Guardian. (2020). Inside Delhi: beaten, lynched and burnt alive. https://www.theguardian.com/world/2020/mar/01/india-delhi-after-hindu-mob-riotreligious-hatred-nationalists

The Guardian. (2020). Coronavirus: 13 April at a glance. https://www.theguardian.com/world/2020/apr/13/coronavirus-latest-at-a-glance 